Brit. J. industr. Med., 1964, 21, 35.

\title{
CHANGES IN ACTIVITIES OF RESPIRATORY ENZYMES IN LUNGS OF GUINEA-PIGS EXPOSED TO SILICA DUST
}

\section{Progressive Effect on the Succinate Oxidase System of Dust Contained in the Lung after Cessation of Dust Inhalation}

\author{
BY \\ T. A. KILROE-SMITH, MARIA G. BREYER, and H. PRINSLOO \\ From the Transvaal and Orange Free State Chamber of Mines Biological and Chemical \\ Research Laboratory, Johannesburg, South Africa
}

(RECEIVED FOR PUBLICATION MARCH 22, 1963)

\begin{abstract}
Previous studies have shown the relation between enzymatic activities in the succinate oxidase system including succinate dehydrogenase, and the early changes in the lungs of guinea-pigs exposed to the inhalation of quartz dust.

We have now investigated whether the increase of enzyme activity depends on maintaining the dust inhalation or not:

Animals exposed to the inhalation of quartz dust for a short period of 28 days, sufficient to produce only small changes in the specific activities of the enzymes, and then removed from the dusty atmosphere for a further period of 113 days showed increases of the same order as animals which remained in the dusty atmosphere for a period of 133 days and were then taken out of this atmosphere for eight days. These increases of enzymatic specific activities are paralleled by increases in lung weight. Hence, in this respect also, the increases in activity of the enzymes follow the same pattern as the fibrogenesis.
\end{abstract}

After exposure of guinea-pigs to quartz dust for a short period, before an increase of collagen can be observed, a process is initiated which causes subsequent increases in the specific activities of certain enzymes, viz. the complete succinate oxidase system and succinate: (acceptor) oxidoreductase (E.C.1.3.99.1) (succinate dehydrogenase) (Kilroe-Smith and Breyer, 1963). It has been established (Breyer, Kilroe-Smith, and Prinsloo, 1964) that the increase is not merely due to the presence of foreign material in the lung but is specifically related to quartz dust.

The fibrogenic activity of quartz is known to be progressive in certain circumstances, such as when used in the technique of intratracheal injection. In this technique a quantity of quartz dust is placed in the lungs of experimental animals, and fibrogenesis continues even though no further dust is put into the lung. The enzymes have therefore been further investigated to determine whether a similar progressive increase is observed in their activities.
Three groups of guinea-pigs, each group consisting of seven male animals randomly selected, were exposed to the inhalation of quartz dust (Table). For controls, two groups of seven guinea-pigs of the same age were used. Two of the three groups of guinea-pigs exposed to the inhalation of quartz dust were removed from the dusty atmosphere after 28 days' exposure. The third group was left in the dusty atmosphere for another 105 days. The lung tissues of one group of seven animals removed from the dusty atmosphere after 28 days' exposure and of one group of seven control animals were assayed for enzyme activity. The assays were distributed evenly over a period of 14 days (average seven days), one dusted and one control animal being assayed on any particular day (Test 1 in Table).

The second group of seven guinea-pigs removed from the dusty atmosphere after 28 days' exposure was kept for a further 105 days under the same conditions as the control animals. The lung tissues of this group and of the third group exposed to continued inhalation of dust, together with those of the control animals, were then 
TABLE

A COMPARISON OF THE EFFECTS ON SPECIFIC ACTIVITIES OF ENZYME SYSTEMS AFTER INHALATION OF QUARTZ DUST FOLLOWED BY A PERIOD OF RESTING, AS OPPOSED TO CONTINUED DUSTING

\begin{tabular}{|c|c|c|c|c|c|c|c|c|c|c|c|c|}
\hline \multirow{3}{*}{$\begin{array}{l}\text { Test } \\
\text { No. }\end{array}$} & \multirow{3}{*}{$\begin{array}{c}\text { Days } \\
\text { Dusted }\end{array}$} & \multirow{3}{*}{$\begin{array}{c}\text { Days in } \\
\text { Dust } \\
\text { Room }\end{array}$} & \multirow{3}{*}{$\begin{array}{l}\text { Days Out } \\
\text { of Dust } \\
\text { Room }\end{array}$} & \multirow{2}{*}{\multicolumn{3}{|c|}{$\begin{array}{l}\text { Ash-free Dry Weight of Lungs } \\
\text { (mg.) }\end{array}$}} & \multicolumn{6}{|c|}{ Specific Activities (units/g. A.F.D.T.) } \\
\hline & & & & & & & \multicolumn{3}{|c|}{ Succinate Dehydrogenase } & \multicolumn{3}{|c|}{ Succinate Oxidase } \\
\hline & & & & Dusted & Controls & D-C & Dusted & Controls & D-C & Dusted & Controls & D-C \\
\hline 1 & 20 & 28 & 7 & $\begin{array}{c}1,050 \\
(860-1,240)\end{array}$ & $\begin{array}{c}830 \\
(650-1,160)\end{array}$ & 220 & 1.06 & 0.86 & $0 \cdot 20^{*}$ & $12 \cdot 6$ & $12 \cdot 3$ & $0 \cdot 3 \ddagger$ \\
\hline 2 & 20 & 28 & 113 & $\begin{array}{c}1,340 \\
(1,120-1,670)\end{array}$ & $\begin{array}{c}880 \\
(740-1,150)\end{array}$ & 460 & $1 \cdot 69$ & $1 \cdot 16$ & $0.53 \dagger$ & $18 \cdot 4$ & $15 \cdot 2$ & $3 \cdot 2 \dagger$ \\
\hline 2 & 90 & 133 & 8 & $\begin{array}{c}1,540 \\
(1,070-2,080)\end{array}$ & $\begin{array}{c}880 \\
(740-1,150)\end{array}$ & 660 & $1 \cdot 73$ & $1 \cdot 16$ & $0.57 \dagger$ & $17 \cdot 9$ & $15 \cdot 2$ & $2 \cdot 7 \dagger$ \\
\hline
\end{tabular}

A.F.D.T. $=$ Ash-free dry tissue.

$\mathrm{D}-\mathrm{C}=$ Dusted minus controls.

*Significant increase (P < 0.05).

+ Significant increase $(P<0.025)$.

$\ddagger$ No significant increase $(P>0 \cdot 10)$.

assayed for enzyme activity after a total of 133 days from the commencement of the experiment. The assays were evenly distributed over a period of 14 days (average eight days). Assays were done using whole lung homogenates. Sets of three animals, one from each of the dusted groups and one from the control group, were used on any particular day, to eliminate variations due to methodology (Test 2 in Table). This enabled the Scheff method of multiple comparisons to be applied to the results for statistical analysis.

Materials and Methods.-Guinea-pigs were exposed to the inhalation of quartz dust as described previously (Kilroe-Smith and Breyer, 1960, 1963), using a concentration of 23,000 to 25,000 particles per cc. throughout.

Sections of the lungs for histological examination, the preparation of the homogenate, the materials used, the methods of enzyme assays, the nomenclature of the enzymes, the units used for expression of results, and the determination of ash-free dry tissue were as previously described (Breyer, Kilroe-Smith, and Prinsloo, 1964).

\section{Results and Discussion}

In the table the effects of continuous dusting are compared with those of a shorter period of dusting followed by a period without exposure to dust. The total time since the start of dusting is the same for the two groups in test 2 , and these are compared with test 1 , i.e. the assays after the short period of exposure to the dusty atmosphere. The figures in the table represent averages of seven animals and duplicate assays on each animal.

Although there was not yet a significant change in the succinate oxidase specific activity in the first test, i.e. 35 days from the start of dusting, the increase in the succinate dehydrogenase activity was significant $(P<0.05)$. This is in general agreement with our previous findings (Kilroe-Smith and Breyer, $1960,1963)$. In the second test, i.e. 141 days from start of dusting, the animals which had been in the dust room for 28 days and then left out of the dust room for the rest of the time were significantly different from the controls $(P<0.025)$ with respect to both succinate oxidase and succinate dehydrogenase. This indicates that the quartz dust, once it has entered the lung, continues to produce increases in the specific activities of the enzymes, even though the animal is removed from the dusty atmosphere before any significant increases in the specific activities are observable (28 days in dust room). As seen in the table, there is no difference between the animals in the dust room for 28 days and those in the dust room for 133 days, provided there is the same time interval since the start of dusting. Hence, a short period of exposure to quartz dust (28 days in dust room) is sufficient to initiate the process, which is not stopped by removal of the animal from the dusty atmosphere but continues in the same way as if the animal had remained in the dusty atmosphere at the same concentration of dust particles per cc. Thus a certain minimal dose of quartz dust, given time to react, is sufficient to bring about the maximum increase in the specific activities of the enzymes for the dose-rate used in these tests. Therefore, in defining the amount of dusting to which the animal has been exposed, it is necessary to state both the total time since the commencement of exposure and the number of days on which dust was blown into the room.

These progressive increases in the activities of the enzymes are paralleled by progressive increases in lung weights based on ash-free dry tissue.

The changes in the activities of the enzymes and in the lung weights occur before any collagenization is observed in the lungs, although there is a slight to moderate increase of reticulin fibres. Histological examination of both dusted and control animals showed the same general features as that of the 
animals reported in Part II (p. 32 of this issue).

The results are of interest in view of the work of Chvapil and Holečková (1959) on the effects of silicic acid and quartz dust on the synthesis of collagen in tissue culture. These authors show that silicic acid in low concentration stimulated collagen synthesis although higher concentrations were inhibitory. Quartz, however, was inhibitory at both concentrations tested. The authors presented the hypothesis that silicic acid in adequate concentration stimulates the activity of some enzymatic system (or systems) of the cells which take part in collagen biosynthesis. It seems probable that the increases which we have demonstrated in the succinate oxidase system (including the succinate dehydrogenase) represent at least a part of these postulated increases in enzymatic activity.
The authors wish to thank Drs. I. Webster, J. S. Harington, and B. Goldstein, of the Pneumoconiosis Research Unit of the South African Council for Scientific and Industrial Research, for supplying the animals and information regarding the pathology of the lungs; Mr. A. Munro for the statistical analysis of the results; and Mr. J. S. Vermaak for technical assistance.

The authors also wish to thank the Transvaal and Orange Free State Chamber of Mines for permission to publish this paper.

\section{REFERENCES}

Breyer, Maria G., Kilroe-Smith, T. A., and Prinsloo, H. (1964). Brit. J. industr. Med., 21, 32.

Chvapil, M.. and Holeckova, E. (1959). Ibid., 16, 286.

Kilroe-Smith, T. A., and Breyer, Maria G. (1960). Proceedings of the Pneumoconiosis Conference, Johannesburg, 1959. Edited by A. J. Orenstein, p. 461. Churchill, London. 